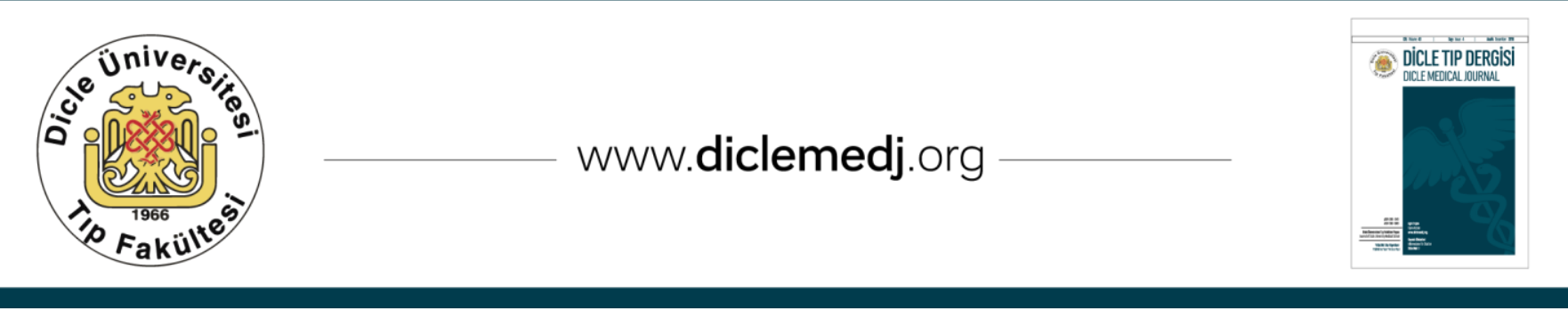

Olgu Sunumu / Case Report

\title{
Mediastinoskopi Girişimlerinde Kardiyopulmoner Bypass Gerektiren Damar Yaralanmalarında Anestezik Yaklaşım
}

\author{
Mediha Türktan', Alper Avcı², Suat Gezer ${ }^{3}$, Orhan Kemal Salih ${ }^{4}$ \\ 1 Çukurova Üniversitesi Tıp Fakültesi, Anesteziyoloji ve Reanimasyon AD, Adana, Türkiye, ORCID: 0000-0002-7378-6265 \\ 2 Çukurova Üniversitesi Tıp Fakültesi, Göğüs Cerrahisi AD, Adana, Türkiye, ORCID: 0000-0001-9337-3030 \\ 3 Çukurova Üniversitesi Tıp Fakültesi, Göğüs Cerrahisi AD, Adana, Türkiye, ORCID: 0000-0002-8476-8839 \\ 4 Çukurova Üniversitesi Tıp Fakültesi, Kalp ve Damar Cerrahisi AD, Adana, Türkiye, ORCID: 0000-0001-5582-5331 \\ Geliş: 14.03.2019; Revizyon: 08.07.2019; Kabul Tarihi: 29.07.2019
}

Öz

Mediastinoskopi; mediastinal lenf noduevrelemesi için gelişmiş görüntüleme yöntemlerine karşın (transtorasik iğne aspirasyonu, torakoskopik biyopsi, endoskopik ince iğne aspirasyonu gibi) halen altın standart olmaya devam etmektedir. Genellikle güvenli bir işlem olmasına rağmen, pnömotoraks, sol rekürren sinir hasarı, trakeal ya da özefagialrüptür ve büyük damar yaralanması nadir görülen ancak korkulan komplikasyonlardır.

Mortaliteye sebep olan en önemli komplikasyonu ise major kanamadır. Bu olgu sunumunda mediastinoskopi sırasında ciddi kanama gelişen ve kardiyopulmoner bypass altında onarım yapılan iki olgunun anestezik yaklaşımı tartışılmıştır.

Anahtar kelimeler: Damar yaralanması, kardiyopulmoner bypass, mediastinoskopi, anestezi.

DOI: 10.5798/dicletip.620646

Yazışma Adresi / Correspondence: Mediha Türktan, Çukurova Üniversitesi Tıp Fakültesi, Anesteziyoloji Ana Bilim Dalı, Adana, Türkiye e-mail:mediturktan@gmail.com 


\title{
Anesthetic Approach for Major Vascular Injuries Requiring Cardiopulmonary Bypass in Mediastinoscopy
}

\begin{abstract}
Mediastinoscopy, still remains the gold standard for mediastinal lymph node staging despite the advanced imaging methods (such as transthoracic needle aspiration, thoracoscopic biopsy, endoscopic fine needle aspiration). Although it is usually a safe procedure, pneumothorax, left recurrent nerve injury, tracheal or esophageal rupture and major vascular injury are rare but feared complications. The most important complication causing mortality is major bleeding. In this case report, we discussed the anesthetic approach of two patients with severe bleeding during mediastinoscopy and repair under cardiopulmonary bypass.
\end{abstract}

Keywords: Vascular injury, cardiopulmonary bypass, mediastinoscopy, anesthesia.

\section{GíRiş}

Mediastinoskopi; mediastinal lenf noduevrelemesi için altın standarttır. Genellikle güvenli kabul edilmesine rağmen, pnömotoraks, sol rekürren sinir hasarı, trakeal/özefagealrüptür, damar yaralanması korkulan komplikasyonlarıdır ${ }^{1}$. Bu sunumda, mediastinoskopi sirasında ciddi kanama gelişen, sternotomi ve kardiyopulmoner bypass eşliğinde onarım yapılan iki olgunun anestezik yaklaşımı tartışılmıştır.

\section{OLGU 1}

Mediastinal lenfadenopati nedeniyle mediastinoskopi yapılacak 48 yaşında kadın olgu bilgilendirilmiş gönüllü olur formu alındıktan sonra ameliyat odasına alındı. Rutin monitörizasyonu (noninvaziv kan basincl, elektrokardiyografi, periferik oksijen satürasyonu) takiben iv propofol $(2 \mathrm{mg} / \mathrm{kg})$, fentanil $(1 \mu \mathrm{g} / \mathrm{kg})$ ve roküronyum $(0.6 \mathrm{mg} / \mathrm{kg})$ ile anestezi indüksiyonu uygulandı. Entübasyon sonrası ek geniş damar yolu açlarak sağ radial arter kanülasyonu yapıldı. Anestezi, total intravenöz anestezi (propofol $260 \mathrm{mg}$, remifentanil $1.6 \mathrm{mg}, 100 \mathrm{cc} \% 0,9 \mathrm{NaCl}$ içinde) ve \%50+50 azot protoksit+oksijen karışımı ile sürdürüldü. Biyopsi sonrası kanama saptanması üzerine cerrahi kanala tampon uyguland. Kanama kontrol edilemeyince sternotomi yapıldı ve sağ pulmoner arter arka duvarında yırtık olduğu görüldü. Kardiyopulmoner bypass altında onarıma karar verilerek pulmoner arter arka duvardaki yırtık onarıldı. Peroperatif $500 \mathrm{~mL} \% 0,9$ izotonik, 500 mLkolloid, 2 ünite eritrosit süspansiyonu, 2 ünite taze donmuş plazma verildi. Entübe olarak reanimasyon ünitesine çıkarılan olgu postoperatif 4. saatte ekstübe edilerek ikinci gün servisine devredildi.

\section{OLGU 2}

Non Hodgkin Lenfoma tanılı 63 yaşında kadınolguya yeni saptanan mediastinal lenf nodları nedeniyle mediastinoskopi planlandı. Bilgilendirilmiş gönüllü olur formu alındıktan sonra rutin monitorizasyonu takiben pentotal sodyum $(3 \mathrm{mg} / \mathrm{kg}$ ) ve roküronyum $(0.6 \mathrm{mg} / \mathrm{kg})$ ile anestezi indüksiyonu yapıldı. Patolojik inceleme sonucunun nüks gelme ihtimali nedeniyle işlemin torakotomiye gidebileceği öngörülerek başlangıçta sol çift lümenli endotrakeal tüple entübe edildi. Ek damar yolu açılarak sağ radial arter kanülasyonu yapıldı. Anestezi idamesi \%0,5-2 sevofluran ve $\% 50+50$ azot protoksit+oksijen karışımıyla sağlandı.

Biyopsi sonrası kanama tespit edilmesi üzerine gazlı bezle bası uygulandı. Bası kaldırılınca kanamanın tekrar başlaması üzerine sternotomi yapılmasına karar verildi. Vena kava superior ve vena azygos bileşkesinde kanama alanı görülerek kardiyopulmoner bypass eşliğinde onarım yapıldı. Peroperatif $1000 \mathrm{~mL} \% 0,9 \mathrm{NaCl}, 2$ ünite eritrosit süspansiyonu, 1 ünite taze donmuş plazma verildi. Entübe olarak kalp damar cerrahisi 
yoğun bakıma çıkarılan olgu postoperatif 2 . saatte ekstübe edilerek 2 gün sonra servise devredildi.

\section{TARTIŞMA}

Pulmoner malignensilerin sinıflaması ve mediastinal hastalıkların teşhisinde yüksek sensitivite (>\% 80$)$ ve spesifiteye $(\% 100)$ sahip olan mediastinoskopi ilk olarak 1959 yılında Carlens tarafından tanımlanmıștır ${ }^{2,3}$. Genel anestezi gerektirmesi, potansiyel komplikasyonları ve tüm noktalara erişim yetersizliği gibi olumsuzluklarına rağmen diğer gelişmiş görüntüleme yöntemlerinin karşısında popülaritesini korumaktadır4 .

Mediastinoskopi sırasinda olası hava yolu problemleri ve komplikasyonlar nedeniyle genel anestezi ve endotrakeal entübasyon uygulanır. Omuz altına rulo konularak baş hiperekstansiyona alınır ve masanın 90 derece döndürmesi anestezistin hava yoluna erişimini daha da zorlaștırabilir. Kas gevșemesi entübasyonda ve işlem sırasında kolaylık sağlar ${ }^{3}$. İnnominate artere bası yanlış ölçüme sebep olabileceğinden, basınç ölçümü sol koldan yapılmalıdır. Ancak, kollateral dolaşımı yetersiz hastalarda innominate arter basisı serebraliskemiyle sonuçlanabilir. Bu nedenle çoğu klinisyen sol koldan kan basıncl, sağ koldan pulseoksimetre takibini uygulamaktadır. Ancak perfüzyon akımı ile dalga görünümü her zaman paralel olmayabilir. Serebrovasküler hastalık hikayesi olan hastalarda sol koldan noninvaziv kan basincı ölçümü yapılırken sağ radial arter kanülasyonuyla serebral perfüzyon takibi yapılması daha doğru bir yaklaşımdır ${ }^{3}$.

İşlem esnasında gelişebilecek damar yaralanması nedeniyle geniş damar yolu açılması önerilir. Vena kava superiora açılan herhangi bir venöz yaralanma olasılığına karşın alt ekstremitelerden venöz erişim önerilmekle beraber Park ve ark, major kanamaların \%71,43'ünün arteriyal kaynaklı olduğunu, bu nedenle alt ekstremite venöz kanülasyonunun olguların en fazla \%25'inde faydalı olacağını belirtmişlerdir ${ }^{5}$. Biz klinik olarak mediastinoskopi uygulanacak olguları, üst ekstremiteden geniş bir ek damar yolu açarak operasyona almaktayız. Kardiyopulmoner bypass eşliğinde onarım yapılmasına karar verilen her iki olgumuza da karar aşamasında femoral ven kateteri takılmıştır.

Mediastinoskopinin morbidite $(\% 0,6-3,7)$, mortalite $(\% 0-0,3)$ ve komplikasyon $(\% 0,5)$ olasılığı oldukça düşük olmakla birlikte, pnömotoraks, sinir hasarı, damar yaralanması gibi komplikasyonlar gelişebilir5,6. Mortaliteye yol açan en önemli komplikasyon major kanama (\%0-0,4)olup en fazla yaralanan damarlar azygosven, innominate arter, pulmoner arter ve bronşial arterdir ${ }^{4,5}$.

Girişim sırasında gelişen 500 mL'den fazla, kan transfüzyonu gerektiren ve sternotomi ya da torakotomiye ihtiyaç duyulan kanama 'major kanama' olarak kabul edilir ${ }^{5,7}$. Kanamaların çoğu direkt bası, gazlı bez ile tamponlama ya da absorbe olabilen materyallerle kontrol altına alınabilmektedir ${ }^{5,8}$. Bu yöntemler; hastaya pozisyon verilmesi, sternotomi ya da torakotomiye hazırlı, arter ve venkanülasyonu, çift lümenli tüp yerleştirilmesi için de zaman kazandırır.

Major kanamalarda gazlı bez ile tampon uygulayarak kanama kontrol edilebilir ancak bu uygulama gazlı bezin çıkarılması için ikinci bir cerrahi müdahaleyi gerektirir ve damar yaralanmasını arttırabilir8,9. Mediasten kapalı bir alan olduğundan, düşük basınçlı sistemlerden (vena cava superior ya da pulmoner arter gibi) kaynaklanan kanamalar büyük hematom ve psödoanevrizmaya sebep olmadan durabilir7. Ancak kanama azygosven veya segmentalpulmoner arter gibi plevraya yakın bir yerden kaynaklanıyorsa hemotoraks veya hemorajik şokla sonuçlanabilir ${ }^{7}$. Bu nedenle konservatif yöntemlerle kontrol altına alınamayan kanamalarda sternotomi veya torakotomiyle onarım gerekmektedir. Park ve 
ark, 3391 mediastinoskopi olgusunun 14'ünde major kanama geliştiğini, 8'inde sternotomi 5'inde ise torakotomiyle tamir yapıldığını belirtmişlerdir ${ }^{5}$.Albage ve ark, mediastinoskopi sırasında gelişen ani kanamayı cerrahi kanala bası ile kontrol etmiş ancak iki gün sonra tamponu çıkarınca posterior duvardan kanama olduğunu görmüşlerdir ${ }^{1}$. Bu olguda aort tam olarak ayrılarak pulmoner arter onarıldığından total sirkulatuvar arrest uygulanmıştır. Kurumumuzda ise 7 yll boyunca gerçekleştirilen toplam 619 mediastinoskopi olgusunun 3'ünde major kanama geliştiği $(\% 0,48)$, bir olguda bası ile kanama kontrolü sağlanırken diğer ikisinde $(\% 0,32)$ kardiyopulmoner bypass altında onarım yapıldığı gözlenmiştir. Ancak hiçbir olgumuzda total sirkulatuvar arrest uygulanmamıştır.

Mediastinoskopi sırasında gelişen major damar yaralanmalarında torakotomi ya da sternotomi altında tamir yapılacak olgularda, başlangıçta kullanılan tek lümenli tüpün çift lümenli tüple değişimi genellikle vakit kaybı olarak değerlendirilmektedir. Lohser ve ark ise zor entübasyon, acil hemodinamik resüsitasyon ya da acil torakotomi ihtiyacı dışında tek lümenli tüpün çift lümenli tüp ile değişimini önermektedir ${ }^{3}$. Pulmoner arter ve innominateven yaralanmaları tek lümenli tüp ile sternotomi yapılarak onarllabilir. Ancak azygosven yaralanmalarında sağ posterolateraltorakotomi gerekebilir ve akciğer izolasyonu damar tamirini büyük oranda kolaylaştırır. Akciğer izolasyonu için bronşial blokerler de kullanılabilir ancak sol bronşial bloker yerleşimi çift lümenli tüp yerleşiminden daha uzun sürer4,10. Her iki olgumuzda da sternotomi eşliğinde tamir yapılmış olup ilk olguda vakit kaybı yaşamamak adına işleme tek lümenliendotrakeal tüp ile devam edilmiş, ikinci olgu ise başlangıçta çift lümenli tüp ile entübe edildiğinden cerrah açısından daha rahat bir onarım gerçekleștirilmiştir. $\mathrm{Bu}$ noktada cerrah ve anestezist iş birliği son derece önemlidir, her iki olgu da aynı cerrahi ekip tarafından opere edilmiş ve anestezi yönetimi aynı anestezi ekibi tarafından verilmiştir.

Önceden geçirilmiş mediastinal cerrahi, antikoagülan kullanımı veya mediastene uygulanan radyoterapi kanamayı arttırabilecek faktörler arasındadır. Ancak çoğu olguda kanamayı açılayacak bir sebep bulunamamaktadır ${ }^{5}$. İlk olgumuzda kanamayı arttıracak patoloji bulunamazken ikinci olgu lenfoma nedeniyle radyoterapi almıștı.

Sonuç olarak; mediastinoskopi genellikle sorunsuz ve güvenli bir girişim olmasına rağmen damar yaralanması gibi majorkomplikasyonların gelişimi açısından anestezist ve cerrah tetikte olmalıdır. Major kanama nadir ancak korkulan bir komplikasyondur ve hastanın monitorizasyon hazırlıkları bu kötü senaryoya göre yapılmalıdır. Doğru yaklaşıma hızla karar verilmesi, hızlı cerrahi müdahale ve hastanın hemodinamik stabilizasyonunun sağlanması hayati önem taşımaktadır.

Sunulduğu kongre: Türk Anesteziyoloji ve Reanimasyon Derneği Ulusal Kongresi 2-6 Aralık 2015, Antalya

Çıkar Çatışması Beyanı: Bu çalışmada çıkar çatışması yoktur.

Finansal Destek: Bu çalışma herhangi bir fon tarafından desteklenmemiştir.

Declaration of Conflicting Interests: There is no conflict of interest in thisstudy.

Financial Disclosure: No financial support was received. 


\section{KAYNAKLAR}

1. Albåge A, Henriksson G, Lindblom D. Repair of acute mediastinoscopic injury to the pulmonary artery using an intravascular approach and deep hypothermic circulatory arrest. Interact Cardiovasc Thorac Surg 2004; 3: 368-9.

2. Carlens E. Mediastinoscopy: a method for inspection and tissue biopsy in the superior mediastinum. Dis Chest 1959; 36: 343-52.

3. Lohser J, Donington JS, Mitchell JD, et all. Case 5-2005: anesthetic management of major hemorrhage during mediastinoscopy. J Cardiothorac Vasc Anesth 2005; 19: 678-83.

4. Lemaire A, Nikolic I, Petersen T, et all. Nine-year single center experience with cervical mediastinoscopy: complications and false negative rate. Ann Thorac Surg 2006; 82: 1185-9.

5. Park BJ, Flores R, Downey RJ, et all. Management of major hemorrhage during mediastinoscopy. J Thorac Cardiovasc Surg 2003; 126: 726-31.
6. Elsayed H. Haemothorax after mediastinoscopy: a word of caution. Eur J Cardiothorac Surg 2012; 41: 1389.

7. Minowa M, Chida M, Eba S, et all. Pulmonary artery injury during mediastinoscopy controlled without gauze packing. J Cardiothorac Surg 2011; 6: 15.

8. Urschel JD. Conservative management (packing) of hemorrhage complicating mediastinoscopy. Ann Thorac Cardiovasc Surg 2000; 6: 9-12.

9. Nagayasu T, Tagawa T, Yamawaki N, et all. Successful management of severe pulmonary artery injury during mediastinoscopy. Gen Thorac Cardiovasc Surg 2011; 59: 73-6.

10. Bauer C, Winter C, Hentz JG, et all. Bronchial blocker compared to double-lumen tube for one-lung ventilation during thoracoscopy. Acta Anaesthesiol Scand 2001; 45: 250-4. 